\title{
The Development of Junior High School Physical Education and Sports Teachers' Training Model to Improve the Professionality in Organizing a Learning in the Era of Industrial Revolution 4.0
}

\author{
$1^{\text {st }}$ Mu'arifin \\ Physical Education, Health and \\ Recreation \\ State University of Malang \\ Malang, Indoensia \\ mu’arifin.fik@um.ac.id \\ $4^{\text {th }}$ Rama Kurniawan \\ Physical Education, Health and \\ Recreation \\ State University of Malang \\ Malang, Indonesia \\ rama.kurniawan.fik@um.ac.id
}

\author{
$2^{\text {nd }}$ Febrita Paulina Heynoek \\ Physical Education, Health and \\ Recreation \\ State University of Malang \\ Malang, Indonesia \\ febrita.paulina.fik@um.ac.id
}

\author{
$3^{\text {rd }}$ Ari Wibowo Kurniawan \\ Physical Education, Health and \\ Recreation \\ State University of Malang \\ Malang, Indonesia \\ ari.wibowo.fik@um.ac.id
}

Abstract - the specific goals of this research are: (a) to study the procedure of the development in the professionality training model of the junior high school sports teachers in organizing a learning, (b) to create a professionality training model that is appropriate for junior high school sports teachers in organizing a learning, (c) to study the testing process of the development in the professionality training model of the junior high school sports teachers in organizing a learning, and (d) to study the result of the development in the professionality training model of the junior high school sports teachers in organizing a learning. This research method used in this research consist of the details of the design, subject, variable, instrument, and the analysis of the research data is presented as follows: the type of research and development to: (1) develop training model for junior high school sports teacher to improve professionality in organizing a learning in the era of industrial revolution 4.0, (2) investigate the effect of the junior high school's training model in improving the professionality in organizing a learning in the era of industrial revolution 4.0. The obtained data is analyzed using a descriptive statistic. The result of the research shows that $93,1 \%$ of the teachers give physical education and sports material in practical way, $74,1 \%$ of the teachers never develop a learning media based on application, $98,3 \%$ of the teachers need a product of the physical education and sports learning media development. The results of the trial are $94,25 \%$ for the small group and $88,38 \%$ for the large group, so the development product are fit to be used as a media for junior high school to learn about physical education and sports.

Keywords- Physical Education and Sports, learning media, development, application

\section{INTRODUCTION}

Education is an effort to enlighten human, teaching a children to be a responsible human. This shows that there is something you cannot find in animal but in human. It is the sense of responsibility. Responsibility is a human awareness that a certain 
action that is bad, wrong, and injustice, needs to be fixed and justified.

The teacher's position in organizing a learning holds an important role. Teacher is one of the deciding factor in achieving the purpose of education that becomes the main indicator of success in the development of a nation. The advancement in the world of education significantly associated with the advancement of a nation. Teachers are hoped to have a multiple ability in teaching so that the learning can be interesting and enjoyed by the student. In the Government Regulation of the Republic of Indonesia Number 74 of 2008 about Teachers, article 48 paragraph 1 states "development and improvement of teacher competence... is carried out through a system of continuous professional development (PKB)".

The improvement of teacher's professionality in a form of training model is an urgent need and need to be done repeatedly. The urgency in training a teacher is oriented in the improvement of teacher's competence in dealing with the rapid development of science and technology, the complex problem with the student itself and the surrounding environment, and the demands of globalization. The continuous training demands continuity in the activity that is centered on the dynamic problem faced and the progressiveness of the activity. Therefore, the training activity can optimize and actualize all the teachers' potential to achieve the expected professionality.

The training of physical education and sports' teacher that is done all this time tend to stop at the training phase (the follow-up training has not been done intensively in the respective schools), even though the good training is done with continuity. Another weaknesses of the common training model is the lack of time for teacher to interact with the trainer or instructor, most of the training process is mono interaction (putting the teacher only as a listener), and the lack of concept understanding and the ability to collaborate with fellow teacher or other party. The professionality development of the new teachers in the recent years use a new model, which is planned systematically as a long term process to encourage growth and professional development [1]. Previously, the professional development consist of workshop or short term courses about new information regarding a certain aspect, that usually is not related with the teacher's job.

The purpose of this research is: (a) to study the procedure of the development in the professionality training model of the junior high school sports teachers in organizing a learning, (b) to create a professionality training model that is appropriate for junior high school sports teachers in organizing a learning, (c) to study the testing process of the development in the professionality training model of the junior high school sports teachers in organizing a learning, and (d) to study the result of the development in the professionality training model of the junior high school sports teachers in organizing a learning. The output from this research is submitted in an indexed international journal scopus: (a) Journal of Teaching in Physical Education, (b) Pediatric Exercise Science Journal, (c) HaKI, and (d) Application.

Physical Education is a physical and spiritual activity that is done in a school through an education process with the hope to achieve the goal of the education. Physical education is a learning process for someone to experience changes in physic, mental, and emotion for the better. So, with it the condition of physical and spiritual of the students are expected to be better [2]. Physical education is a very good arrangement and thought for the process of developing attitudes, and that is beneficial to physical activity and sports at the same stage as important as teenagers. Then students consider a physical education important and will be useful for their future and this is one of the main goals of the teacher [3]. The goal of physical education is to develop potential and give chances to students to have an aspect in mental, emotion, social, physic, moral, and physical fitness [4].

Learning is a process that include many phases, start with the easier (repeating or mimicking/using) to the difficult phase. The capacity to learn becomes the reason that differentiate human with other species. The success of a learning is influenced with the attitude and perception connected with the completion of tasks in class [5]. The organizing of learning is a series of activity in planning, implementing, and evaluating a learning. This is in line with the Regulation of the Minister of Education and Culture No. 65 of 2013 concerning the Standards for Primary and Secondary Education which explains that standards process include planning the learning process, implementing the learning process, assessing learning outcomes, and supervising the learning process.

Planning is a process in preparing things that needed for the learning process. Implementation is an implementation of the plan in the class, which is marked with the multi-interaction between students, teacher, and the learning material. Assessment is an activity to find out the effectiveness and efficiency of learning process. In a learning process, interaction between students, teacher, learning material shows a dynamic learning behavior in making a decision. Learning behavior is connected with decision making. Every intentional action from a learning is the result of previous decision making [6]. Learning behavior is based on the level of subject involvement (teacherstudents) in making a decision on the planning phase (pre-impact), implementation (impact), and evaluation (post-impact).

Learning media is a form of communication that can be used to give information from the learning 
source to the students. The purpose is to stimulate students to engage in learning activity. Besides used to fully deliver the learning, it also can be used to give a certain part of the learning activity, giving enforcement or motivation to the students [7]. Media is a tool to send messages to the students in a learning process in order to achieve effective learning [8]. Learning media is needed in learning so the students easily absorb the information or messages given by the teacher. Therefore, the goal of the education can be achieved.

Media in learning is one of the helpful instrument used by the teacher in a learning process that is effective to give out learning material to the students that has many purposes so the students do not feel bored and able to stimulate students so they are motivated and understand the learning with ease [9]. Learning media is a means to deliver a message and learning information that will help students if it is planned correctly [10]. It can be inferred that learning media can be planned or developed with the student needs that will help them understand the message from the learning media. An ideal study of the cognitive effectiveness of alternative instructional media would relate a vector of output measures relevant to a subject matter, including criterion-referenced measures of achievement, to the time pattern of instructional inputs. This function would include as independent variables factors not under the control of the school system so that, in its allocation of resources, the system could provide, to the extent desirable, different patterns of resource inputs to different categories of student [11].

The accomplishment of learning management in school requires the teacher to give their best effort to improve the competence mastery so the learning runs effectively [12]. One of the effort to achieve effectiveness in learning is by participating in the Forum of Subjects' Teachers (MGMP). MGMP is an activity outside the learning process in the class and it is organized. It is the place where teachers discuss about the problem regarding their tasks that aim to increase the quality and professionalism of a teachers in teaching at junior high school [13].

MGMP consist of numbers of teachers that has different teaching method and different students' characteristics, so they can discuss and share their experience, and also find the solution for the problem that they faced in the class [14]. Therefore, MGMP is planned to facilitate the needs of the subjects' teacher in order to improve the learning quality, so the learning activity can be improved, if the quality of teacher is also improved. Through MGMP, every subjects' teachers are able to interact and exchange their thoughts to fill and complete their professional ability with the purpose of creating a teaching and learning standard in the class to achieve the goal of education [15].
From the perspective above it can be concluded that Forum of Subjects' Teacher (MGMP) is a gathering of certain subjects' teacher with the purpose of increasing the learning quality, facilitate the teachers' needs, and improving the teachers' professionality in teaching their subjects especially in junior high school.

\section{METHOD}

The training design is the planning of things that linked to the organization of teacher's training. Pribadi (2014:66) described one of the design model for learning that is systematic and comprehensive to be used in designing effective and efficient training program is invented by Dick and Carey [16]. The model is called The Systematic Design of Instruction [17], the steps to create learning design is shown on the following table.

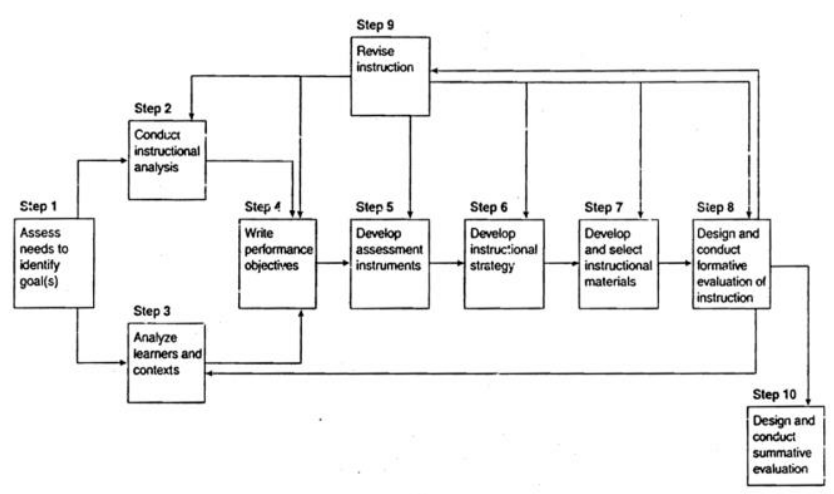

Figure 1. Dick and Carrey design model of learning system

The procedures that is used in this research are consist of seven steps, which are: (1) Need analysis, (2) identifying the aspirational model that is wanted by the physical education and sports teacher in junior high school, (3) developing an early model, (4) expert validation, (5) conducting small scale trial, (6) conducting field trial using action research, and (7) develop the final model.

\section{RESULT}

The following is an illustration of one of the products for developing junior high school physical education and sports learning media: 


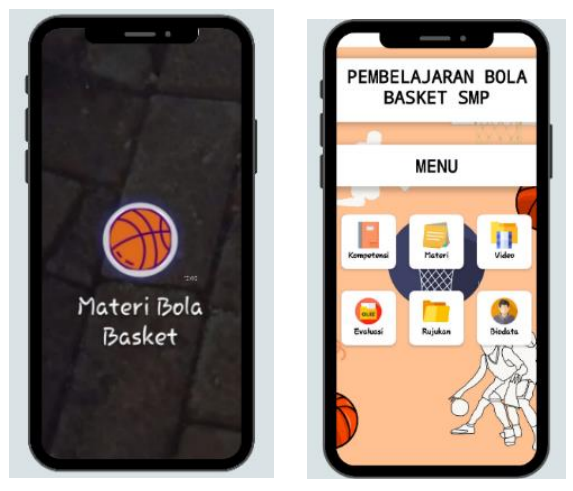

Figure 2. the example of the view of the icon and the main menu of the application

The following are the results of the expert validation, small group and large group trials which are presented in the form of tables and diagrams:

Table 1. The result of analysis and validation of the learning's expert

\begin{tabular}{lcc}
\hline \multicolumn{1}{c}{ Aspect } & Appropriateness & Descrpition \\
\hline Compatibility & $93,75 \%$ & Very Valid \\
Clearness & $91,6 \%$ & Very Valid \\
Easiness & $87,5 \%$ & Very Valid \\
Accuracy & $100 \%$ & Very Valid \\
Effectiveness & $100 \%$ & Very Valid \\
\hline \multicolumn{1}{c}{ Validity } & $90 \%$ & Very Valid \\
\hline
\end{tabular}

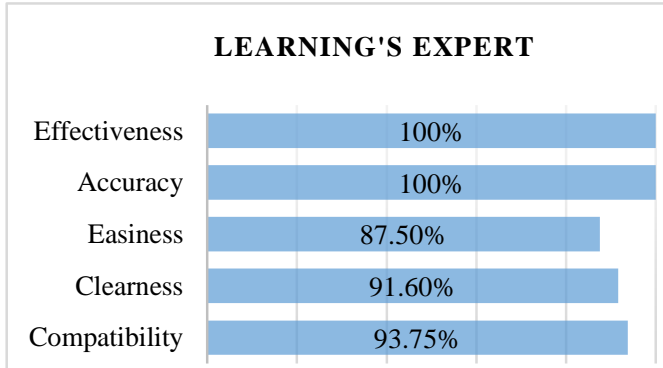

$0.00 \% 20.00 \% 40.00 \% 60.00 \% 80.00 \% 100.00 \%$

Figure 3. Learning's Expert Data Analysis Diagram

The data analysis obtained a percentage of $90 \%$ from the validation of the learning's experts which was then converted according to the assessment category with very valid results.

Table 2. The result of analysis and validation from material's expert

\begin{tabular}{lcc}
\hline Aspect & Appropriateness & Description \\
\hline Clearness & $75 \%$ & Valid \\
Accuracy & $75 \%$ & Valid
\end{tabular}

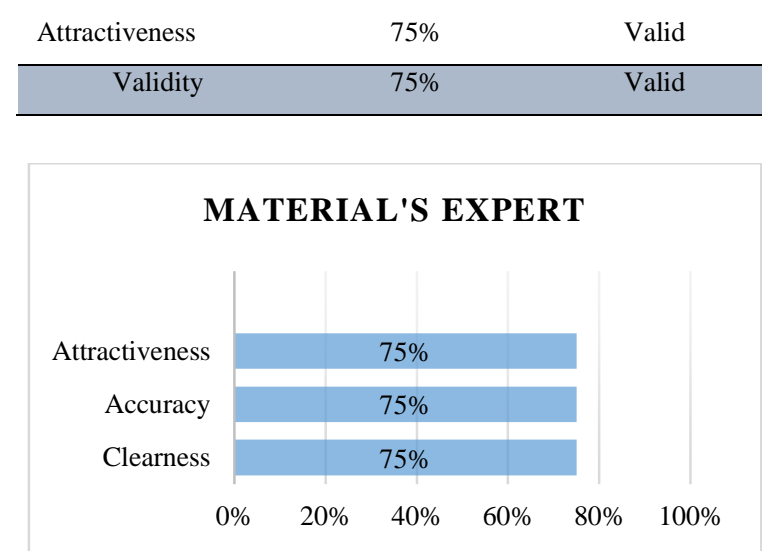

Figure 4. Material's expert data analysis diagram

The results of the data analysis obtained a percentage of material's expert validation of $75 \%$ which was then converted according to the assessment category with valid results.

Table 3. The result analysis and validation of media's expert

\begin{tabular}{lcc}
\hline \multicolumn{1}{c}{ Aspect } & Appropriateness & Description \\
\hline Attractiveness & $97,5 \%$ & Very Valid \\
Compatibility & $100 \%$ & Very Valid \\
Clearness & $100 \%$ & Very Valid \\
Accuracy & $100 \%$ & Very Valid \\
Easiness & $100 \%$ & Very Valid \\
\hline \multicolumn{1}{c}{ Validitas } & $99,10 \%$ & Very Valid \\
\hline
\end{tabular}

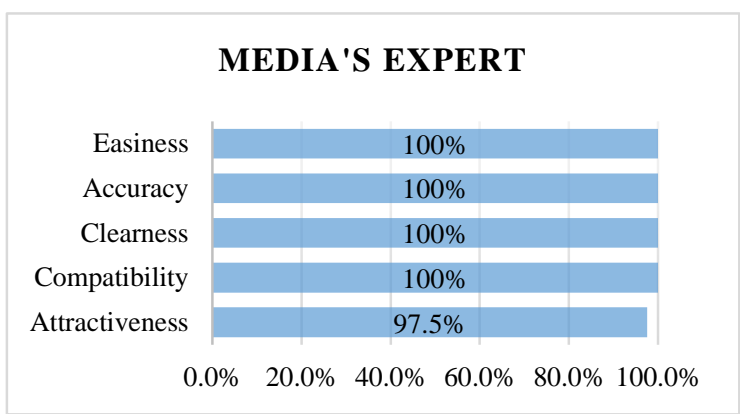

Figure 5. Media's expert data analysis diagram

The data analysis obtained a percentage of $99.10 \%$ from media's expert validation which was then converted according to the assessment category with very valid results.

Tabel 4. Small group trial analysis results

\begin{tabular}{lll}
\hline Aspect & Appropriateness & Description \\
\hline Compatibility & $96,38 \%$ & Very Valid \\
Clearness & $92 \%$ & Very Valid \\
Accuracy & $92,5 \%$ & Very Valid \\
Attractiveness & $93,75 \%$ & Very Valid
\end{tabular}




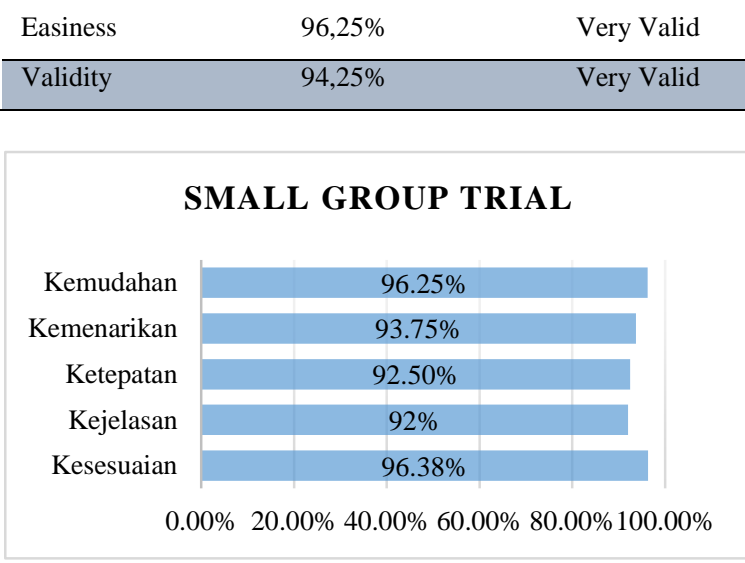

Figure 6. Small group trial analysis diagram

The data analysis obtained a percentage of $94.25 \%$ which was then converted according to the assessment category with the product results classified in the very valid category.

Table 5. Large group trial analysis results

\begin{tabular}{lcc}
\hline \multicolumn{1}{c}{ Aspect } & Appropriateness & Description \\
\hline Compatibility & $89,07 \%$ & Very Valid \\
Clearness & $87,5 \%$ & Very Valid \\
Accuracy & $88,33 \%$ & Very Valid \\
Attractiveness & $89,58 \%$ & Very Valid \\
Easiness & $86,25 \%$ & Very Valid \\
\hline \multicolumn{1}{c}{ Validity } & $88,38 \%$ & Very Valid \\
\hline
\end{tabular}

\section{LARGE GROUP TRIAL}

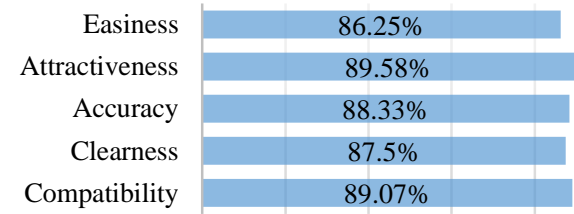

$0.00 \% 20.00 \% 40.00 \% 60.00 \% 80.00 \% 00.00 \%$

Figure 7. Large group trial analysis diagram

The data analysis obtained percentage of $88.38 \%$ which was then converted according to the assessment category with the product results classified in the very valid category.

\section{DISCUSSION}

This research produce a learning media product which is an application based on $i$-spring, kodular and java that can be installed and use through smartphone with ease and can be accessed either in offline or online. The available menu on the application are core competence/basic competence (KI/KD) menu, learning material, videos, evaluation, references, and the biodata of the researcher. The learning app also includes e-book and learning video that is designed attractively especially physical education and sports (PJOK) learning material for Junior High School (SMP). On the application it also has an evaluation tool in a form of quiz. On the video menu, the learning video is divided into three, (1) video for the $7^{\text {th }}$ grade, (2) video for the $8^{\text {th }}$ grade, and (3) video for the $9^{\text {th }}$ grade, which will help the teacher in giving out the lesson. The learning product will be used in junior high school that is expected to help learning and teaching physical education and sports. This learning media gets good assessment on the functionality and the application can be accepted, the installation on the smartphone does not meet any problem, and gets approval rating from the users with $88 \%$ which is considered to be very appropriate [18]. Learning media based on application can accessed anywhere and anytime because it is in a form of a software on a smartphone [19]. One of the media that can be used and run smoothly on android smartphone is android studio and java [20].

Based on the need analysis, it shows that $98,27 \%$ PJOK teachers needed learning media to be developed in a form of application with the goal to attract the students' attention. Learning needs a media that will be used to achieve the goal of the learning, attracts the students, and makes the learning activity becomes more structured [21]. There is an increase on the students after receiving learning material using the learning media, those are: 1) learning process become more interesting, 2) students' learning efficiency is improving, 3) helps students concenctrate on learning, 4) improving students' learning motivation, 5) giving a whole experience on learning, 6) students are engaged on the learning process [22].

The validation analysis result of the expert on media shows that the development of a product based on application is good on general and appropriate to be used in a learning situation, so the developed product suitable as a learning media that will support the teachers in explaining learning topic and direct the learning process. To achieve a learning goal, we can utilize a learning media. Some of the strength of learning media based on application that will enhance students' learning result is to become a supplement have the quality as an alternative, complementary, and substitution [23]. In order to make the learning process to be effective and pleasant, it is suggested to use a meda, that will attract the students [24].

The role of learning media is important in learning process on this era, students will have a difficult time if the learning media are not suitable [25]. Learning media is a means to help in learning process so the learning material can be delivered clearly and reach the learning goal [26]. Learning media also hoped to help maximalize the learning processs inside and outside of classroom. It also motivates the students to study happily and actively, so it attain the expected learning results [27]. The learning that is made using an application (construct) can help in having an effective, efficient, and interesting learning [28]. One of the form of learning media is audio visual. Audio visual is one of 
the type of learning media, video is able to support teachers in the process of presenting some difficult learning material. Therefore, learning media in form of video helps students and teachers in a learning process [29]. I-Spring is a software tool that convert presentation file that compatible with power point and change it into flash form in the implementation of the learning product that is resulted from this progam and then, it is made to be an android [30].

\section{CONCLUSION}

Based on the results of the trial analysis in the MGMP PJOK SMP, the results of the small group is $94.25 \%$ and the large group is $88.38 \%$. In conclusion, the product of the development is qualified to be used as a learning media to learn physical education and sports (PJOK) for Junior High School.

\section{REFERENCES}

[1] E. V. Reimers, Teacher Professional Development: An International Review Of The Literature. UNESCO, 2003.

[2] Akhmad, Sumber Belajar Penunjang PLPG 2016. 2016.

[3] J. M. Murcia, D. Coll, and L. P. R, "Self-Determined Motivation and Physical Education Importance. Human Movement," Hum. Mov., pp. 5-11, 2009.

[4] A. Paturusi, Manajemen Pendidikan Jasmani dan Olahraga. Jakarta: PT Asri Mahasatya, 2012.

[5] R. J. Marzano and D. J. Pickering, Dimensions of learning. teacher's manual, 2nd Edition. Aurora, Colorado: McREL (Mid-continent Regional Educational Laboratory)., 1997.

[6] M. Mosston and S. Ashworth, Teaching physical education, 4th ed. Ed. Macmillan: College Publishing Company., 1994.

[7] N. Uno, B. H. \& Latamenggo, Teknologi Komunikasi \& Informasi Pembelajaran. Jakarta: PT. Bumi Aksara, 2011.

[8] A. A. Naz and R. A. Akbar, "Use of Media for Effective Instruction its Importance : Some Consideration," J. Elem. Educ., vol. 18, no. 1-2, pp. 35-40, 2010.

[9] Rohani, Media Pembelajaran. Sumatera Utara: Universitas Islam Negeri Sumatera Utara, 2019.

[10] A. Muhson, "Pengembangan Media Pembelajaran Berbasis Teknologi Informasi," J. Pendidik. Akunt. Indones., vol. 8, no. 2, 2010, doi: 10.21831/jpai.v8i2.949.

[11] D. Jamison, E. T. Service, and P. Suppes, "The Effectiveness Of Alternative Instructional Media," no. October 1973.

[12] Muhajir, Pendidikan Jasmani, Olahraga, dan Kesehatan SMP/MTs Kelas VII. Jakarta: Kementerian Pendidikan dan Kebudayaan Repiblik Indonesia, 2017.

[13] S. Wulandari, "Analisis Pelaksanaan MGMP IPS SMP/MTs dalam Meningkatkan Profesionalitas Guru di Kabupaten Sijunjung Tahun 2017," J. Buana, vol. 2, no. 1, p. 362, 2018, doi: 10.24036/student.v2i1.84.
[14] P. Najri and P. Jambi, "MGMP Dalam Meningkatkan Keprofesionalan Guru Mata Pelajaran," vol. 10, no. Juni, pp. 130-144, 2020.

[15] W. Hermawati, "Pengaruh Motivasi Kerja Guru dan Implementasi Program Kerja Musyawarah Guru Mata Pelajaran (MGMP) Terhadap Kinerja Mengajar Guru di MTS Negeri Model Brebes," vol. 2, no. 9, p. 6, 2017.

[16] B. A. Pribadi, Desain dan pengembanagan program pelatihan berbasis kompetensi. implementasi model ADDIE. Jakarta: Prenada Media Utama., 2014.

[17] W. Dick, L. Carey, and J. Carey, The systematic design of instruction. Columbus, Ohio: Person., 2015.

[18] R. Setiawan, "Rancang Bangun Media Pembelajaran Berbasis Android Tanpa Coding Semudah Menyusun Puzzle," J. Sist. Inf. dan Sains Teknol., vol. 2, no. 2, pp. 17, 2020, doi: 10.31326/sistek.v2i2.729.

[19] Y. S. Pangestu and D. Setyadi, "Pengembangan Media Pembelajaran Aplikasi Android Pytha Fun untuk Teorema Pythagoras SMP,” J. Cendekia J. Pendidik. Mat., vol. 4, no. 1, pp. 113-125, 2020.

[20] R. F. Wijaya, R. B. Utomo, D. Y. Niska, and K. Khairul, "Aplikasi Petani Pintar Dalam Monitoring Dan Pembelajaran Budidaya Padi Berbasis Android," Rang Tek. J., vol. 2, no. 1, pp. 123-126, 2019, doi: 10.31869/rtj.v2i1.1093.

[21] F. A. Ashfahany, S. Adi, and E. Hariyanto, "Bahan Ajar Mata Pelajaran Pendidikan Bentuk Multimedia Interaktif Untuk Siswa Kelas Vii," J. Pendidik. Teor. Penelitian, dan Pengemb., vol. 2, no. 2, pp. 261-267, 2017.

[22] T. Nurrita, "Pengembangan Media Pembelajaran Untuk Meningkatkan Hasil Belajar Siswa," MISYKAT J. Ilmuilmu Al-Quran, Hadist, Syari'ah dan Tarb., vol. 03, no. 01, pp. 171-187, 2018.

[23] Y. Maryeni, "Aplikasi E-Learning sebagai Model Pembelajaran berbasis Teknologi Informasi," J. Vokasi, vol. 9, no. 1, pp. 27-39, 2013.

[24] R. Novita and S. Z. Harahap, "Pengembangan media pembelajaran interaktif pada mata pelajaran sistem komputer di SMK," Informatika, vol. 8, no. 1, pp. 36-44, 2020

[25] M. Ayu, F. M. Sari, and M. Muhaqiqin, "Pelatihan Guru dalam Penggunaan Website Grammar Sebagai Media Pembelajaran selama Pandemi," Al-Mu'awanah $J$. Pengabdi. Kpd. Masy., vol. 2, no. 1, pp. 49-55, 2021.

[26] N. M. Dwijayani, "Development of circle learning media to improve student learning outcomes," J. Phys. Conf. Ser., vol. 1321, no. 2, 2019, doi: 10.1088/17426596/1321/2/022099.

[27] Y. Sari, D. Pujianto, and B. Insanistyo, "Pengaruh Metode Bermain Terhadap Hasil Belajar Senam Lantai Roll Belakang Pada Siswa Kelas Viii Smp Negeri 4 Bengkulu," Kinestetik, vol. 2, no. 1, pp. 75-80, 2018, doi: 10.33369/jk.v2i1.9190. 
[28] F. Ridho, B. S. Anggoro, and S. Andriani, "Aplikasi Android Contruct 2 untuk Media E-Learning pada Materi Peluang," Desimal J. Mat., vol. 2, no. 2, pp. 165-171, 2019, doi: 10.24042/djm.v2i2.4037.

[29] W. Waziana, L. Anggraeni, and N. L. Sari, "Penerapan Aplikasi Pembelajaran Bahasa Inggris Dasar Berbasis
Multimedia," J. TAM ( Technol. Accept. Model ), vol. 7, pp. 22-26, 2016.

[30] E. N. Sastrakusumah, "Pengaruh Media Pembelajaran Interaktif Berbantuan Aplikasi Ispring Presenter Terhadap Kemampuan," vol. 3, 2018. 